Within the twenty-year period that coincides with the first twenty years of the Glej Theatre, the essay concentrates on the formation and transformations of non-hierarchical theatre communities, or, in the words of one of its founders, Dušan Jovanović, theatrical tribes. Using historical and present-day examples, the author will try to map the specific devised theatrical procedures producing what Badiou names "a generic vacillation": "Theatre turns every representation, every actor's gesture, into a generic vacillation so as to put differences to the test without any supporting base. The spectator must decide whether to expose himself to this void, whether to share in the infinite procedure. He is summoned, not to experience pleasure (which arrives perhaps 'on top of everything', as Aristotle says) but to think" (Rhapsody, 124).

The essay strives to answer the following questions: How did the Slovenian experimental and non-institutional performing arts scene (as a reaction to the hierarchical structure of repertory theatres] create different non-hierarchical modes in relation to creating the performances, the theatre's artistic direction and forming temporary communities with emancipated audiences? To which models did this scene turn - then and today - to develop its own logic of devised and collaborative theatrical tactics? And lately: To what extent have those different artistic collaborative tribes changed the theatrical landscape in Slovenia, Yugoslavia and elsewhere?

Keywords: artistic collective, performative turn, neo-avant-garde, experimental theatre, non-institutional art

Tomaž Toporišič, PhD, is a dramaturg and theatre theorist, an associate professor of the history and theory of drama and performing arts and vice-dean of the Academy of Theatre, Radio, Film and Television, University of Ljubljana. His primary research interests are contemporary performing arts, literature and visual culture. He is the author of four books on contemporary performing arts. His latest essays include: "The New Slovene Theatre and Italian Futurism", "(Re)staging the Rhetoric of Space" and "Deconstructive Readings of the Avant-garde Tradition in Post-Socialist Retro-avant-garde Theatre". He was the artistic director and dramaturg of the Mladinsko Theatre and co-founded the Exodos Festival of Contemporary Performing Arts. 


\section{Collectives, Communities and Non-Hierarchical Modes of Creation from the 1970s till the 1990s ${ }^{1}$}

Tomaž Toporišič

University of Ljubljana, Academy of Theatre, Radio, Film and Television

Within the twenty-year period that coincides with the first twenty years of the Glej Theatre, the essay will concentrate on research into the formation and transformations of non-hierarchical theatre communities or, in the words of one of the founders, Dušan Jovanović, theatrical tribes. Using examples from past and present, I will try to arrive at answers to the following questions: In what way did the Slovenian experimental and non-institutional performing arts scene (as a reaction to the hierarchical structure of repertory theatres) employ different non-hierarchical approaches to creating the performances, the theatre's artistic direction and the forming of temporary communities with emancipated audiences? To which models did this scene turn to develop its own logic of devised and collaborative theatre tactics? To what extent have those different artistic collaborative tribes changed the theatrical landscape in Slovenia, Yugoslavia and elsewhere?

\section{From collectives and tribes of the 1970s to non-hierarchical creative approaches in "independent" theatre and the performing arts scene}

As Barbara Orel points out in her essay "Experimental Theatre", the performing arts have had a rich history in Slovenia since the 1950s, with their roots going back to the first half of the $20^{\text {th }}$ century. In the second half of the century, they have been denoted in different ways: "experimental theatre" until the end of the 1970s, "alternative theatre" in the 1980s, "independent theatre" in the 1990s, and "non-government sector production" as the most suitable term after 2000. Like other Eastern and Central European countries, Slovenian experimental theatre has combined aesthetic

1 The article was written within the research programme Theatre and Interart Studies P6-0376, which is financially supported by the Slovenian Research Agency.

Članek je nastal v okviru raziskovalnega programa Gledališke in medumetnostne raziskave P6-0376, ki ga financira Javna agencija za raziskovalno dejavnost Republike Slovenije iz državnega proračuna. 
challenges with an oppositional political stance:

The breaks in the theatre tradition in terms of diverging from the traditional aesthetic principles and mimetic representation have been influenced by an intermedial dialogue with other arts, media and technologies, and have transformed the theatre field into the wider sphere of the performing arts. Theatre innovations have been decisively shaped by the search for new lifestyles, which have created new environments of existence, experiences in Slovenian society. (Orel, "Experimental" 295)

In accordance with this interpretation, we can see the history of Slovenian post-WWII theatre as a series of interactions between opposing but at times very constructive and creative relations between the institutional-repertory theatre scene and experimental, alternative and, later, non-institutional performing arts, often referred to as "amateur and dilettante" by the "drama theatre" critics.

Within the Slovenian theatre of the second Yugoslavia (1945-1991), the experimental theatre communities thus became a specific, alternative space to the politically supervised and ideologically regulated mainstream artistic and cultural scene within the self-managing socialism. The guardians of the regime (the Communist Party, later to become the League of Communists) were not only vigilant over the institutional repertory theatres. They paid particular attention to experimental theatre practices that were (irrespective of their level of socio-political engagement) always considered by the authorities as provocative art or political theatre, for which an upper tolerance limit needed to be set (Toporišič, Levitve drame 140-41). As historian Peter Vodopivec points out in his book From Pohlin's Grammar to the Independent State. Slovenian History from the End of the 18th Century till the End of the 20th Century, the Communist Party leaders were aware that "... a more free and pluralist cultural atmosphere was an important outlet for the intellectual and wider dissatisfaction of the people; on the other hand, they also understood that the opening of the cultural sphere threatened the monopoly of their fundamental beliefs and ideology" (356).

We will start our analysis with a look into the experimental theatres and performance groups at the turn of the 1960s to the 1970s, that is, during the performative turn from textual to body culture. In our investigation, we will begin with the decision of these groups to exclude classical theatre actors from their circle, replacing them with non-professional performers with no formal theatre education. To a certain extent, their decisions were influenced by the theory and practice of American and European theatre avant-gardists. They related to the work and methods of Richard Schechner and The Performance Group, as well as the theatre of Eugenio Barba and Jerzy Grotowski, Bread and Puppets Theatre and others. And one cannot neglect the influence of the actions of The Living Theatre, presented in Yugoslavia for the first time in 1967, that invited their audience to protest and join in a common act of bodily 
and sexual liberation on or off the stage. The performance and the consequences of Antigone and Paradise Now, by all means, the most famous example of the "loving communities", reveal not only the reawakening of the ritualistic character of 1960s' art but also a different notion of community and its collaborative structure.

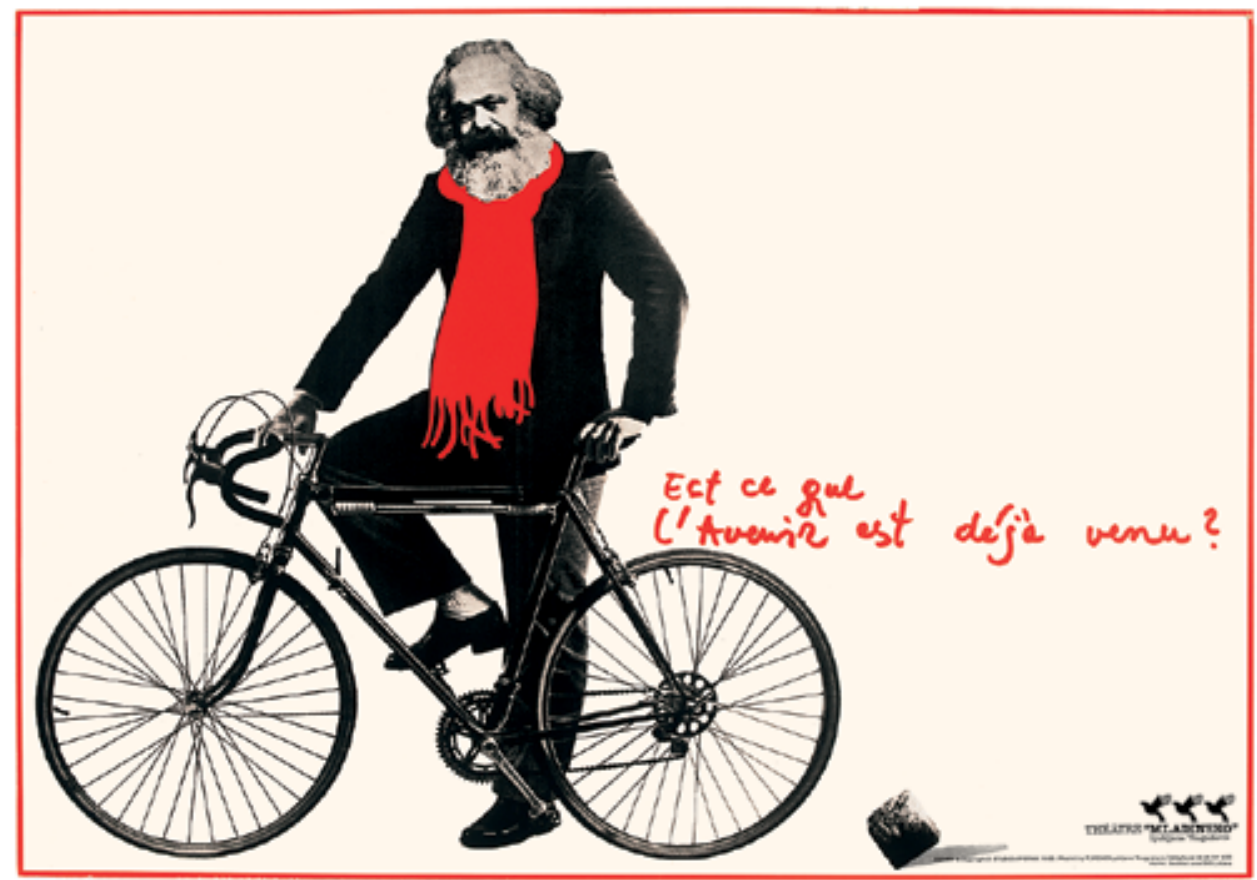

The poster for the Mladinsko Theatre Tour in France in the 1980s (design by Matjaž Vipotnik), Archive of Mladinsko Theatre.

"It is self-evident that nothing concerning art is self-evident anymore, [...] not even its right to exist" (Adorno 1).

When speaking about the new situation of art in the society of the spectacle, the German philosopher Theodor W. Adorno could also be referring to the Slovenian theatrical experiment of the second part of the $20^{\text {th }}$ century. This experiment (according to Veno Taufer) "created a distinct and recognisable profile of theatre which could be designated as an idiosyncratic type of ritual theatre in search of some basic theatre signs or acting and mise-en-scène expressions of such signs of human existential practice" (Taufer, "Rudi Šeligo" 154-5)

This new experimental theatre, practised by various groups, succeeded in overwhelming Yugoslav festivals of alternative and student theatre. It became synonymous with the resilience and endurance of small theatre groups, which proliferated during the 1970 s and started to present an alternative to the professional 
repertory theatre with formally educated actors. These groups were practising new communities, built as communities of equals, friends, brothers, sisters and lovers or (to use the words of Dušan Jovanović) "tribes", who could all "be together" in the present time of the performance as a sensation and a pleasure, but also the aesthetic reorientation of perception and sensuality.

For this theatre of opposition in the aesthetic and political sense, the Vjesnik newspaper from Zagreb introduced an interesting term, "theatre guerrilla". It claimed that this guerrilla gained the upper hand against the flagship "theatre cavalry" of the 1970s. These new communities were nevertheless quite far from the political guerrilla: they can better be defined as loving communities, very different from the militant collectives with their ghostly characters. The Slovenian experimental theatres and communities of the 1970s were thus practising collaborative structures and approaches to work, and trying very hard to keep crossing, including permanently, the borders between art and life.

Nevertheless, Lado Kralj - most probably the "ideological" and "spiritual" leader of the new performative revolution of the 1970s deriving a lot of its ideas from Schechner, Foreman and the New York avant-garde - highlighted the origin of the Pekarna Theatre and other performance groups of the 1970s also within the tradition of Slovenian experimental theatres: particularly the Oder 57 (Stage 57), the Experimental Theatre and the Ad hoc Theatre. However, he also emphasised that this was a politically engaged, "class theatre" looking for its own means of expression: new theatre communities wanted to develop their own methods that were participatory as well as involving a specific psycho-physical acting training. These new theatre communities emphasised theatre as ritual and the group or collaborative creation of the performances. Kralj's interest was not in experimental or avant-garde theatre, as practised by the Glej Theatre. This approach to theatre was not radical enough, as it aspired "to be better and more progressive than traditional theatre" (Kralj, "Zanima me razredno gledališče" 21). For him, theatre should go beyond the bourgeois theatre Brecht criticised. It should establish a new type of artistic community, no longer a mere theatre, but an "aesthetic action, as ritual, as speaking the unspeakable" (Ibid.).

Like Grotowski and Schechner, for Kralj, the process in theatre was more important than the final product. What was at stake was experimentation with the very "essence of acting and human impersonation, about relationships between the physical and the psychological" (Kralj, "Hipijevsko" n.p.). The critics seemed not to have understood Kralj's aims, but Pekarna actors themselves were well-aware of this new relationship between the physical and the psychological. They were aware that the Pekarna Theatre "defied the theatre mastodons with mere peanuts from the cultural community. In the spirit of Stanislavsky, Grotowski and Brook, it restarted the theatre wheel of history which politicians so violently stopped with Oder 57." (Slana 27). 
The aesthetic revolution of Kralj's concept of Pekarna was specific in its goal: it searched for new ways to connect the main priorities of the American neo-avantgarde performative turn with the situation of the student generations in socialist Slovenia. In the words of Lado Kralj, their aim was "to find and define a home ground, to refresh it, reshape it according to the needs of our audiences and social space, to change it or maybe even reject part of it" (Lado Kralj on the Pekarna Theatre, quoted in Andres 112).

The Pekarna Theatre found its aesthetic and political identity in close dialogue with the Polish (Grotowski, Kantor) and American theatre avant-garde (Schechner, Chaikin ...). At the same time, it burst forth from the specific cultural and political situation of the non-aligned Yugoslavia. Looking back at his work of the 1970s, Lado Kralj defines this situation as follows:

Richard Schechner, my mentor, stripped the halo of religious rapture off Grotowski and added elements of absurdist theatre, as well as irony and the grotesque, topped with anthropological research into the tribal culture in New Guinea and Australia, and bizarre aspects of Americana [...]. (Svetina, Pekarna)

What he learned from the dialogue with Schechner, he adapted to himself and his generation in Slovenia and established the Pekarna Theatre.

How can we draw a "morality" from this statement: indubitably, the very idea and concept of the Pekarna were established in close dialogue with diverse phenomena of contemporary performative practices at the intersection of East and West, socialism and capitalism. In this dialogue, the boundaries of the reception and interpretation of contemporary art in experimental and student theatres at the time were shifted. And this led to a specific breaking down of the hierarchy and dichotomy between high culture and popular, between capitalist and socialist culture.

\section{A new classification and dehierarchisation of the theatre landscape at the transition from the 1960s to the 1970s}

Writing and commenting on the $4^{\text {th }}$ International Student Theatre Festival in Zagreb in 1964, Lado Kralj formed a new, revolutionary classification of contemporary theatre. He introduced new categories, among them, student theatre as something that could be compared to both professional repertory theatre on the one hand and amateur or dilettante theatre on the other.

He highlighted the specificities of student theatre as experimental theatre: "a very special layer of acting, different from both professional and amateur performers. [...] 
Student theatres, however, belong to that larger group of theatres, which, for want of a better term, I will dub experimental" ("Mednarodni" 1238-39).

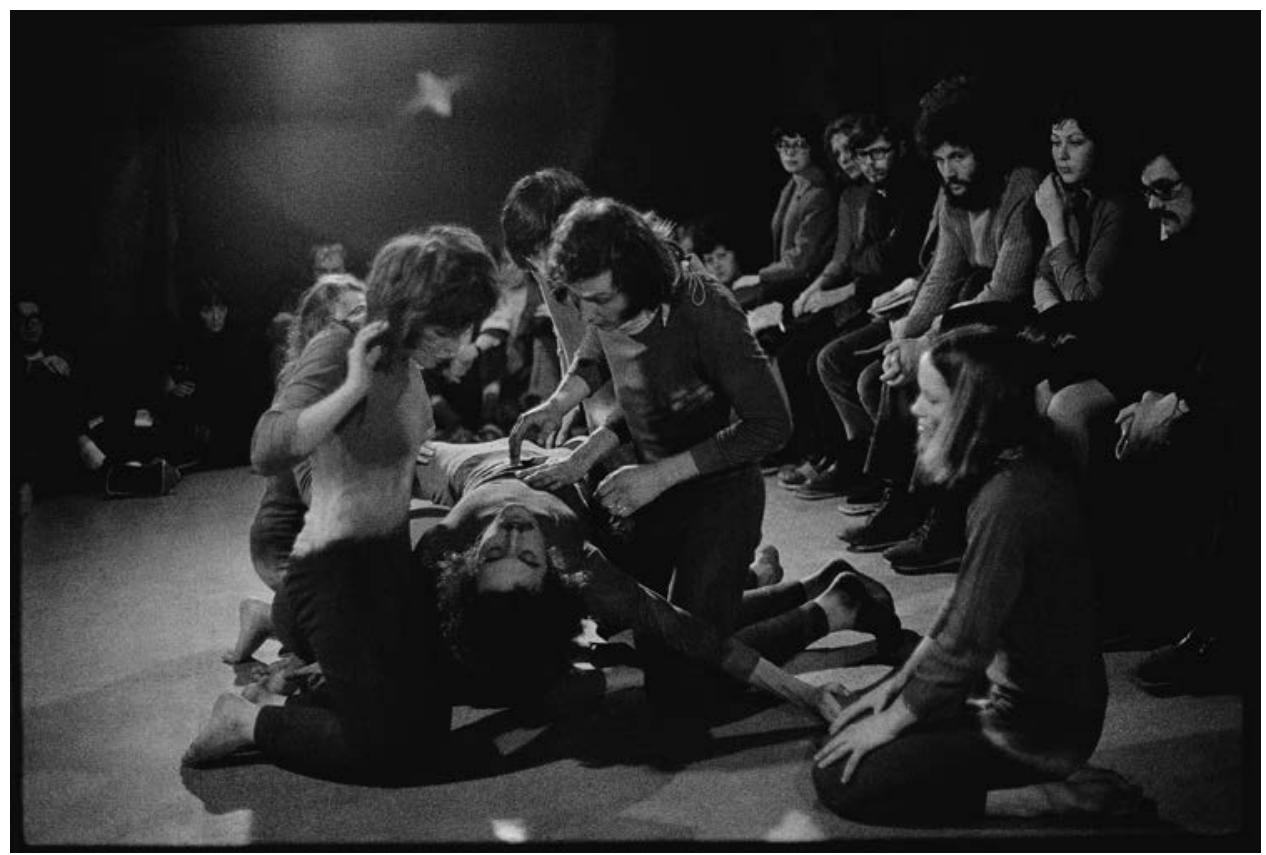

Lado Kralj's first staging of The Pathwalker by Dane Zajc in 1972, Pekarna. Photo: Tone Stojko, Iconography SLOGI.

Kralj's classification was highly revolutionary at a time when the professionalisation or rather Europeanisation of the acting and other theatre professions had barely finished in Slovenia and Yugoslavia. According to his persuasions, the student and non-student experimental theatres allowed both professional and nonprofessional theatre people to mix:

They are characterised by a kind of continuous experimentation that affects not only their manner of stage expression and selection of the repertoire but also the ensemble itself: by experimenting with acting, they are constantly testing their attitudes towards social reflection and attempting to affect it creatively. (Ibid. 1239)

And not only this, he was convinced that both student and experimental theatre workers could produce "an accomplished conception of the role of theatre in society" as they not only fulfil the basic role of the theatre as a profession but also "as an inalienable part of their immediate presence in society, through which they attempt to reach some kind of active correspondence with society" (Ibid.). Thus, experimental and student theatres are very different from conventional theatres and do not tend to merge with them. 
When looking back to the history of the Pekarna Theatre (which he established together with Kralj and Ivo Svetina), one of the most influential and consequential experimental artists and thinkers, Peter Božič, confirmed most of the ideas of young Lado Kralj. He pointed out that experimental theatres focused on "completely new principles of horizontal dramaturgy with a different sensibility/awareness of time" (Božič, "Eksperimentalno pozorište ..." 320). Božič furthermore linked this horizontal structure of artistic creation and theatre organisation of the theatrical tribes or communities as something that could be linked to Edvard Kardelj's idea of self-management in socialism: a representation of "a consistent approximation to the ideal of self-management, author, director, costume designer, technician, etc." (Ibid.).

Lado Kralj's and Peter Božič's concepts of a specific experimental theatre and its communities were but the tip of the iceberg of the performative turn in the Slovenian performing arts scene that introduced tectonic shifts to the understanding of the theatre. The new generation that has to be linked to student and neo-avantgarde movements suddenly became aware that nothing was self-evident in art and society: not even the division of the actors into drama (matrix), student (experimental, non-matrix) and amateur (spontaneous non-professionals), or the society into capitalist and communist.

To summon up the conceptual changes and main outlines of the Slovenian experimental and student theatrical scene in the late 1960s, we can once more use the arguments that Lado Kralj published in the journal Sodobnost in 1969 as a part of a special theme devoted to the Slovenska gledališka situacija (Slovenian theatre situation). He defined the experimental theatrical landscape of the time as a community "seeking out and defining 'social minorities' and the 'social majority', enabling each one appropriate affirmation since only such a situation allows for radically new solutions surpassing the level of personal quarrel and exhausting running in circles" (Kermauner et al. 593). Kralj's argument, which was most likely shared by his contemporaries, especially Dušan Jovanović and his circle of the Pupilija Ferkeverk Group and the Glej Experimental Theatre, is again very much to the point, challenging the borders of theatre and society in the $1960 \mathrm{~s}$ (and to some extent also today). 


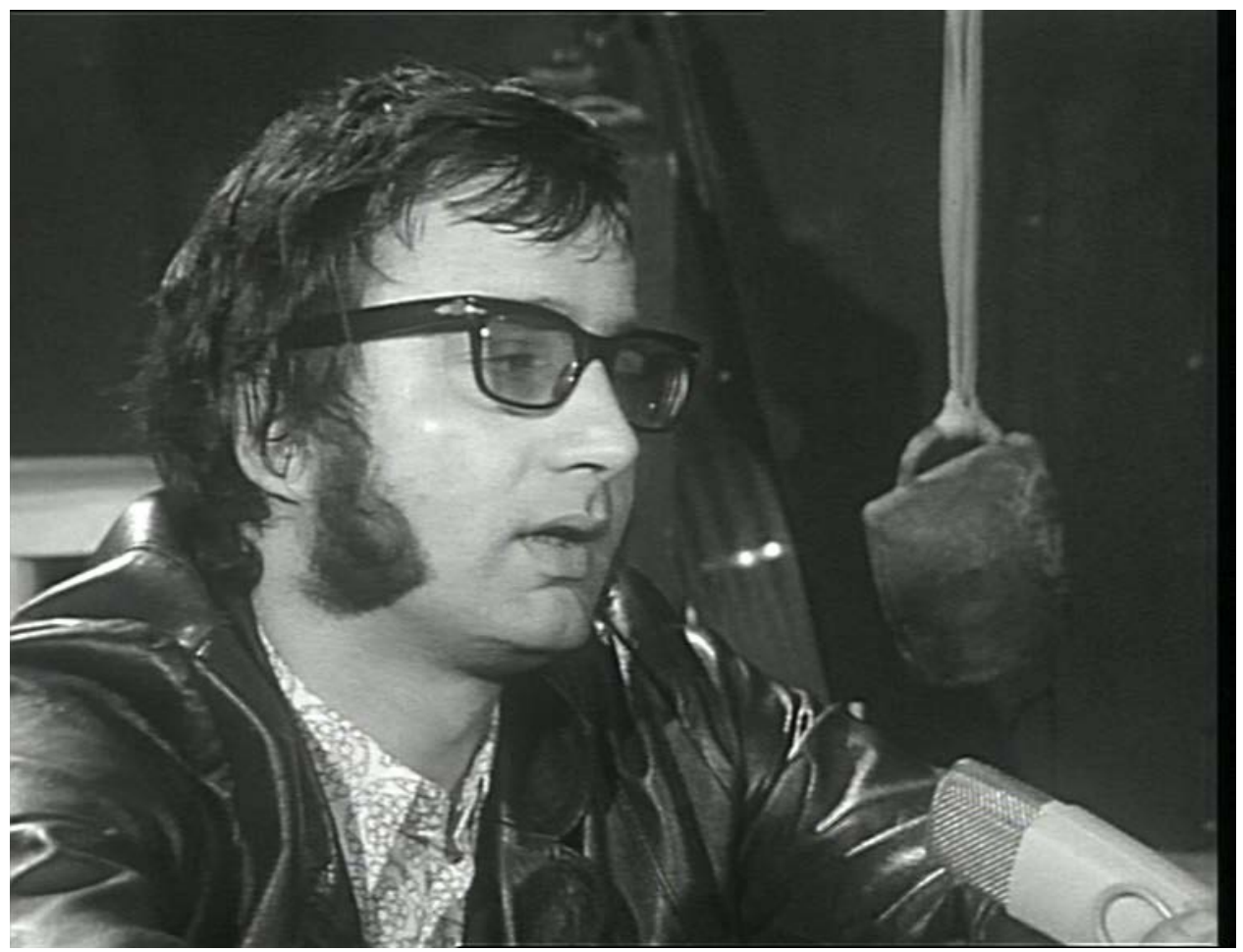

Lado Kralj at the beginning of the 1970s. Still from TV Slovenia Archive.

Kralj demanded clearly demarcated areas of activity in both the repertory and experimental theatrical scenes. Experimental theatres should concentrate on "experiments in the area of performance, acting, the idea of theatre, the dismantling or deconstruction of the only Slovenian theatre form - the Burgtheater adaptation of Stanislavsky - replacing it with new, unattested experimentation with mixed media, the radicalisation of gesture, word, stage technique, etc." (Ibid.). They were the ones that could take the kind of risks that the national and other repertory theatres, situated at the very centre of the cultural and theatre semiosphere, could not.

However, the repertory theatres should nevertheless not be understood as fortresses of tradition: they should absorb experiment into their functioning, which is in its nature primarily informative and aimed at representing the nation. Both types of theatre should maintain their respective logic and sense but maintain a clear and intense dialogue between the two theatrical communities to "establish a normal correlation between institutional and experimental theatre" (Ibid.). 


\section{The tribe of Pupilija Ferkeverk and Dušan Jovanović}

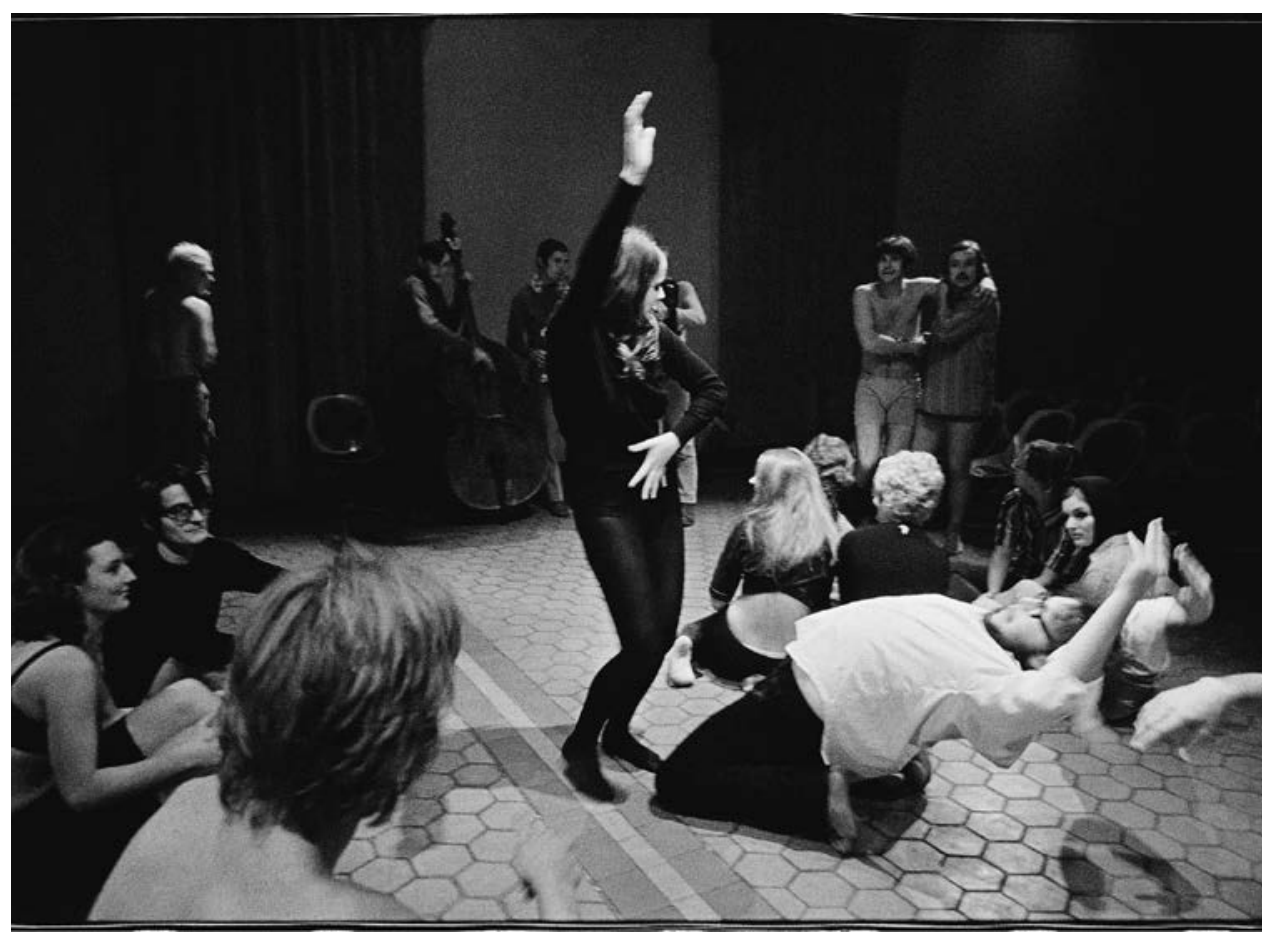

The tribe of Pupilija Ferkeverk in 1969. Photo: Tone Stojko, Iconography SLOGI.

Kralj's thoughts about theatre were very close to the thoughts of together with the predominately visual arts community $\mathrm{OHO}$ probably the most influential artistic community of the 1960s within the field of the performing arts, Pupilija Ferkeverk. In 1970, while performing in Zagreb, Pupilija published its mini-manifesto in the student newspaper Studentski list. It reads:

We want to destroy the basic characteristics of traditional and some avant-garde theatres, which is the illusion of life to which theatre has always been subservient. The performance is no longer a play, a copy, or enactment of life but rather a total and all-encompassing reality [...]. Performers are no longer actors [...], the actor is on equal terms with the spectator, while the performers, through their presence, create a concrete social [?] environment [...]. The Pupilija Ferkeverk Theatre is an experimental, non-literary, open and living theatre ("Gledališče Pupilije Ferkeverk").

Pupilija wanted to replace the theatre performance with an event - an action. The actor, or rather protagonist of the theatre event, thus became "an authentic and physical figure. [...] There is no more pretence onstage; nothing is feigned, everything is happening for real, and it really happens. [...] The actors' resources are adapted to 
this end so they can use them to really function, as they really cause blood to flow. The blood actually flows onstage" (Toporišič, Performativni obrat 230).

Their starting point was shared and most probably influenced by the today-famous neo-avant-garde visual arts group OHO in the 1960s: the alertness of their senses, the specific way in which materiality was understood in this Slovenian visual and other arts collective. Both groups shared the idea of exploration of the performativity of language, nature and everyday gestures. Their practices might have had different ideological and aesthetic backgrounds, but they show many similarities. They were both interested in a specific community, in which bodies collaborate on or off stage, in theatre and everyday life, and alliances are made between libidinal energies and common imaginations. For Pupilija and OHO, being together was grounded mainly in desire, in the disclosure of intimacy.

Pupilija was a student-experimental community of non-professional actors who never intended to be anyone but themselves. They introduced a specific practice of acting, based on Johan Huizinga's notion of play in his highly influential book Homo Ludens ${ }^{2}$ (this practice can be compared to Michael Kirby's theory of notacting, published in his 1972 TDR article "On Acting and Not-Acting"), replaced professionalism and drama with non-professionalism and non-drama, the actor with a performer. Pupilija was a performative community that no longer wanted to be hierarchical, but rather a "tribe", of which Dušan Jovanović, who in many ways steered Pupilija, wrote: "I became a fan of the tribe. For a long time afterwards, I missed the tribe, a community where I could feel at home" (92). Like Kralj, Jovanović perceived Pupilija as an aesthetic, political reaction to the deceptive harmony of society and its official art:

Pupilija was not art with a capital A. According to professional standards, it was almost dilettante. But it contained the liberating power of parody, ritual sacredness and a thirst for unlimited freedom. [...] Pupilija had an unusual power; it had a culture of authenticity typical of tribal communities (Ibid. 91).

The representative of the Oder 57 generation and highly influential theatre scholar and dramatist, Primož Kozak, placed this in a broader context:

This is no simple matter, even though it often seems like a youthful whim and the eccentricity of "those damn artistic brats". What is happening, [...] touches upon the very foundations of our life, not just our national life, but our life as a culture. [...] We cannot just say it is simply a fashion that will pass or some nonsense from which we must avert our youth or an imitation of the decadent West that must be thwarted. It is here, and it will go on in one form or another. (26)

2 The influence of this book is described by Dušan Jovanović in his highly interesting essay Pleme, konfrontacija in kolaž (Tribe, Confrontation and Collage). 
According to the dramaturg and theatre scholar Eda Čufer, Pupilija symbolised within the Slovenian scene a demand for the pluralisation of theatrical models, a gesture of an innocent need to widen the notion of theatre (28). Or, as Primož Jesenko sees it: Pupilija confronted theatre as an institution, and its vision contradicted the norm (455).

\section{Dušan Jovanović and the Glej Experimental Theatre (eksperimentalno gledališče Glej)}

Kralj's ideas were a bit more radical than those of the Glej group - Dušan Jovanović, Igor Lampret, Zvone Šedlbauer, Samo Simčič, Lučka Simonič, Iztok Tory and Matjaž Vipotnik. In fact, the Glej Experimental Theatre began its journey to being the longest surviving experimental theatre in Slovenia (celebrating 50 years in 2020) on 25 June 1970 with a premiere of Kaspar by Peter Handke, one of the most influential new dramatists and theatre reformers of the time. Its name (the word glej is Slovenian for "to watch" or "look") stressed the group's commitment to a different theatrical perception. One of the founding members of the group, Kralj remembered the circumstances of its establishment:

The idea of putting together a new alternative theatre group formed at the end of 1969, when Dušan Jovanović and Zvone Šedlbauer approached me. Soon after that, Igor Lampret, Marko Slodnjak and Iztok Tory joined the group. The ensemble was recruited quickly and spontaneously from the students at the Academy for Theatre, Radio, Film and Television. ("Hipijevsko, čutno, razpuščeno")

As Barbara Orel sums up, Glej and Pekarna were but the tip of the iceberg of the experimental theatrical communities and approaches of the 1970s:

In the 1970s, performance research ranged from "poor theatre" (with reference to Jerzy Grotowski) to multimedia theatre. Poor theatre gave rise to unique concepts of ritual theatre forms. The following communities provided an original Slovenian contribution to European theatre: the group of Tomaž Kralj (who continued the work of the Gledališče Pupilije Ferkeverk and realised the concept of "untranslatable theatre"); the Vetrnica (Windmill) group by Vlado Šav (developing an original variant of the "meeting" between the actors and the spectators); and so-called "group theatre," practiced by Lado Kralj's Pekarna on the basis of the anthropological research into play and environmental theatre by Richard Schechner. This generation, which sprang from hippy culture, was followed in the late 1970s by the generation establishing itself under the increasing influence of the mass media and pop culture. Through the paradigm of performance theatre, they paved the way to multi-media theatre (in the projects of the student alternative FV 112/15, Dušan Pirih Hup, the Pocestno gledališče Predrazpadom (Streetwalking Predesintegration Theatre) group, the Gledališče Ane Monró (Ana Monró Theatre), Meje kontrole št. 4 (The Borders of Control No. 4), and the first groups in Yugoslavia consisting solely of female authors: Podjetje za proizvodnjo fikcije (Fiction Production Company) and Linije sile (Lines of Force). All of them attempted 
to abandon the field of aesthetics and were reproached for alleged instrumentalisation of amateurism. ("Experimental" 297)

Once more, the mainstream theatre critics adopted a reserved stance; they seemed to fail to recognise the experimental and "independent" theatre, performance and intermedia art as a part of Slovenian theatrical culture. However, this is a story we are going to reopen in the 1980s.

As we have seen already from the arguments of Lado Kralj, the new generation was far from satisfied with the political and cultural situation in theatre and society. Thus, Dušan Jovanović criticised the status quo and provinciality of the situation in Naša sodobnost: "We are more or less behind in everything that is new, progressive in Europe. Moreover, we are not behind only at the level of new tendencies, experiments and studies, but also at the level of the known, established, traditional models of our profession, craft, technology. We do not have an experimental theatre or an avantgarde theatre ..." (“Odgovor"1171).

Glej was the fruit of the theatrical revolution of Pupilija, joining the forces of students from the AGRFT (Academy for Theatre ...), some young actors from the Slovenian National Theatre (SNT) Drama Ljubljana, headed by Dušan Jovanović and Lado Kralj, an assistant professor of dramaturgy at the academy that proposed the name in the spirit of the neo-avant-garde. A few weeks after the première of Handke's Kaspar, the group formed the theatre with Kralj stating that it was the fruit of the awareness of the need for experimental activities in contemporary theatre. Soon after the founding, Kralj noted that his interest was not in the experimental or avant-garde theatre practised by Glej (which he co-founded with Jovanović, Šedlbauer and others). In his opinion, this theatre was not radical enough, as it aspired "to be better and more progressive than traditional theatre" (Kralj, "Zanima me razredno gledališče" 21). For him, this theatre was no better than the bourgeois theatre Brecht criticised. He aimed to establish a new type of theatre, which would no longer be mere theatre, but an aesthetic revolution or "aesthetic action, as ritual, as speaking the unspeakable" (Ibid.).

Primož Jesenko describes the situation within the experimental theatre scene at the beginning of the 1970s:

When in the summer of 1971, Lado Kralj returned from a year off with professor Richard Schechner and The Performance Group in New York, he disagreed with his former colleagues about the need to approach the institutional method of production. He disagreed with the creative principle that Glej had developed during the year of his absence. Due to the influence of the New York avant-garde, Kralj founded the Pekarna Theatre, an additional "free group of theatre workers". Glej let him leave with people and carry out his work in the spirit of developing Grotowski's ritual theatre and social therapy as a goal and effect. The group settled in the former bakery at Tržaška cesta 15 
Lado Kralj himself commented on the situation: "It was said that I was perhaps right, but they did theatre differently, that they were masters of thatis and that they would not do anything differently. There was no conflict, just a realisation that cooperation would not work. They even gave us a part of the finances from the Cultural Community to Glej, and we invested it into transforming the former bakery into a theatre" ("Čutil sem", 10).

Let us take as an example of collaborative work a performance of Dušan Jovanović, ${ }^{3}$ Monument $G$, a highly unusual performative staging of a play by Bojan Štih in which the director, together with the choreographer Lojzka Žerdin and dramaturg Igor Lampret, wanted to implement Jerzy Grotowski's poor theatre and elaborate a different experience from that of the Pupilija Ferkeverk group.

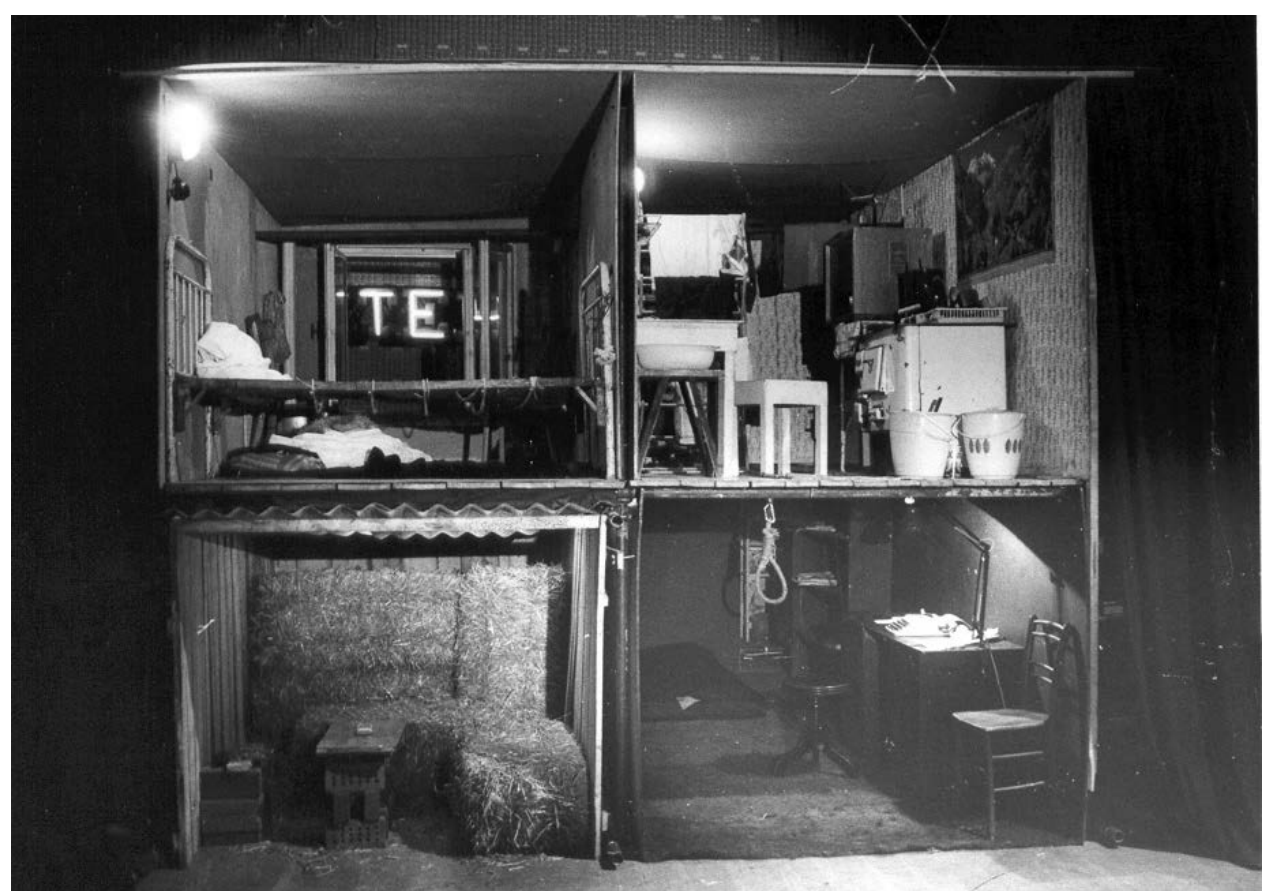

The scenography of So So by Mirko Kovač, directed by Ljubiša Ristić, Pekarna Theatre, Iconography SLOGI, 1974

\footnotetext{
3 Together with Zvone Šedlbauer and Iztok Tory, Dušan Jovanović was in the inner circle of the directors working for this group. Among his important works for Glej were: Victor, or Power to the Children (Victor ou les enfants au pouvoir) by Roger Vitrac (22 January 1971), Spomenik G (Monument G) by Jovanović and Bojan Štih (28 January 1972), Kdor skak, tisti hlap (He Who Jumps is a Serf) by Rudi Šeligo (26 January 1973), Živelo življenje Luke D. (Long Live the Life of Luka D.) by Pavle Lužan (23 January 1974) and Pogovor v maternici koroške Slovenke (Conversation in the womb of a Carinthian Slovene woman) by Janko Messner, Tomaž Šalamun and Jovanović (5 October 1974).
} 
Glej produced a new form of theatre that was based on the theatrical event. This was a Yugoslav phenomenon. "At approximately the same time Atelier 212 was formed in Belgrade, Theatre ITD in Zagreb, and we all displayed tendencies that were completely different from those in theatre institutions. We realised that compromises were no longer possible, as this would have led to an aesthetic and ideological defeat" (EG Glej). There was a clear connection between these views and the student revolt that demanded social revolution and the transformation of all traditions. (217)

Jovanović's first attempt at aesthetic revolution was within the Student Actual Theatre (ŠAG - Študentsko aktualno gledališče) in the second half of the 1960s, before the creation of Pupilija. He continued in some productions in the 1970s, most notably directing Štih's play Spomenik (Monument) at the Glej Experimental Theatre in 1972, about which Veno Taufer wrote: "But Jovanovič preserved both sides of the text. [...] Only that he denied the text as literature, destroyed it as such, re-created it as theatre. Thus, Štih remains a co-author of the Monument, which the director returned to him as a personal experience of total theatre" (Odrom ob rob 50).

Or as Peter Božič, another protagonist of the aesthetic avant-garde of the 1960s and 1970s, lucidly describes in his interpretation of the Glej performance and its turning points: "In this performance, Dušan Jovanović abolished the mediator between the actor's body and his play, which we call intellect or reason" ("Razvoj" 37). Thus, the actress Jožica Avbelj achieved the exclusion of rational or conscious work in her Artaudian interpretation and "the text was reduced to semantic signs or a sound mass, which they also interpreted semantically according to the changed structure" (Ibid.). The director, who before Monument $G$ staged in Glej his homage to Vitrac's play Victor or Children in Power, wrote a highly interesting testimony of this most radical cut with the text in Glej's history: “I took Štih's Monument very seriously, but I was quite disturbed by the traditional structure of the piece and its engagement. [...] I wanted the things in the text to come to light physically, not verbally. [...] Of the seventy pages of the text, nine sentences, one poem and a few cries remain. Through the dialectic of twelve poses, Jožioca Avbelj performed the content of the entire Štih piece" (Jovanović, All these experiments ... n.p.).

According to Andrej Inkret, an influential critic of the time, the play "in the first phase of the rehearsals started from Štih's striking cultural-political-critical satirical happening". Then it gradually eliminated the literary template, reduced the performers to a minimum, until the only "surviving" actress "remained with a series of torn, independent sentences (completely neutral fragments from Štih's texts), from which it is hardly possible to recognise the template ..." (Inkret, Milo za drago 332-33). Inkret further notes that the text in Monument $G$ has been "removed" and concludes that 
Jovanović's performance is "the extreme limit of the 'negative' or 'negativist' attitude towards the text, derived radically to the lower limit on the other side of which begins the world of 'pure theatre"'(Ibid. 333).

Thus, with Monument $G$, if we use Pavis's label, Jovanović boldly embodied the fact that "theatre directing is not a performative translation of a text" ("Od teksta" 147).

Not unlike Lado Kralj, Dušan Jovanović saw his role in Glej and theatre in general as a person trying in every way to establish a tribal atmosphere within a specific artistic community. While doing so, he met with many obstacles, one of them being the actor and his specific socialist psychology, which he defined as follows: "An actor is a member of a trade union which defines him and his social role, the role of an employee [...] I came to this conclusion after I tried to change a professional ensemble into a social group, to introduce a participative process into theatre" (Prišli so Pupilčki 93).

As Gašper Troha points out, "here, Jovanović talks about his artistic leadership of the Mladinsko Theatre in the 1980s" (215). Still, the theme of difficulties when eliminating the basic theatrical hierarchy and unionism is a constituent part of all his thoughts about the possible aesthetic revolutions in theatre.

\section{Vlado Šav and his shaman's open theatre of active culture as a continuation of the model of the poor theatre of Jerzy Grotowski}

Vlado Šav, a contemporary of Jovanović and Lado Kralj, proposed his own version of a performative revolution, closely linked to Grotowski, one of the world's most influential figures in independent theatre. Šav developed the methods and ideas of his own original version of an intercultural theatre seeking the universal principles that shape not only the theatre but also human action in a performance situation. Thus he opted for theatrical activities that could enable the community practising it to make a complete departure from the bourgeois and repertory model of the theatre at the turn of the 1960 s to the 1970 s.

Šav, who graduated in drama acting in 1970 from the Academy for Theatre, Radio, Film and Television in Ljubljana, successfully entered the selection for a six-month specialisation at Jerzy Grotowski's Acting Institute at Teatr Laboratorium in Wrocław, Poland, in 1973. As early as September 1973, after returning from Poland, Šav founded the group Vetrnica and started gradually developing various (existential and performative) practices of active culture. ${ }^{4}$ With his group, he practised the ideology

4 The work of Šav with Vetrnica was a continuation of his explorations of the community works and happenings he started with his first performance collective Beli krog (White Circle) at the end of the 1960s. 
of primitivism derived from Grotowski and Schechner (Innes 1-5), which (like Kralj and Grotowski) he built on an alternative scale of values concerning contemporary culture and society. But his main goal was a specific return to nature and the fellow human being, a specific version of the third theatre in the sense of Eugenio Barba, putting in dialogue intellect and body. In a similar way to Kralj (who, in his own words, dealt at the Pekarna Theatre with Slovenian pathology and schizophrenic society), Šav introduced an extreme version of the return to the roots, the origins, and "antimaterialism directed towards spirituality (interest in religion and other spiritual practices of non-European cultures, experimenting with techniques of reaching altered states of consciousness, an inclination for founding ritual communities and blurring the boundary between performers and spectators), and belief in the transformative, or rather therapeutic force of ritual (self-)representation" (Schuller 400).

Beginning his career as an actor at the Koper City Stage (Mestni oder Koper, 19641968) already during his studies, he quickly made a radical turn by founding and heading the experimental theatre group Beli krog (White Circle). Its "manifesto" was the abolition of the distinction between professional and amateur, acting and notacting, theatre and ritual. This activity was an introduction into Šav's para-theatre, or rather, a theatre of the active culture or rather a theatrical "meeting" that is not a performance but a meeting between the group and the audience. ${ }^{5}$ The group "followed the example of The Living Theatre, as well as the laboratorium-style, introspective acting expression of Grotowski", while the performance "presented its attitude towards the world which might seem a bit too simplistic, lacking in problematisation and critique", nevertheless, "a promising start of successfully posited work in the formal as well as the specifically-expressive sense" (Povše 20-21). His performance Pot (The Path) was thus environmental, placed in a meadow. Performers and spectators were separated merely by a white chalk circle; it emphasised performative rituality, an autopoietic feedback loop between performers and spectators formed through physical and vocal actions by the performers who were not acting out roles but attempting to express who they were by using archetypes.

In the spring of 1974, the group Vetrnica ${ }^{6}$ organised a special performative event, which was entitled Srečanje (The Meeting). It was conceptualised as "the spontaneous improvisation of individuals who endeavoured to involve everyone present in unified action through their expressive strength" (Šav, "Gledališče kot intenzivno življenje" 4):

5 For a detailed analysis and synthesis of the crucial elements of Šav's specific concept of theatre, see Alexandra Schuller's essay "Vlado Šav in aktivna kultura" (Vlado Šav and Active Culture).

6 The group was founded in September 1973 in Ljubljana as part of the student cultural association Forum. It was active from 1973 until 1981. Its members included Vesna Dvornik, Milan Kristan, Jani Osojnik, Slavica Rukavina, Vlado Šav, Zdena Virant and Andrej Žumer. The group was also active internationally, touring in Europe and to Israel and Canada. 
This can hardly be called a play since members of the group do not represent anything; instead, they are who they are. It is something different, something that still lacks a name. We make use of the terms: confrontation, soirée, meeting. [...] This isn't theatre in the traditional nor the modern sense, but something utterly new, singular [...] a meeting between a visitor and the group, a meeting of certain people in space, close contact between them, a moment of relaxation, a moment when perfect strangers join in that which is most beautiful and intimate to humans. It is a psychological and physical activity shared by everyone present. Each member of the group takes on this mission; they attempt to create such moments, to discover that most profound in themselves, and to pull everyone present into this experience of the self, thus triggering a similar experience in them as well. To meet with the Other as human to human ("Študentsko gledališče Vetrnica" 20).

Šav succeeded in demolishing the border between the performers and spectators, who in his theatre became fellow actors and co-created the performances by participating in the play, that is, through their physical presence, their perception and their reactions forming a specific society and a specific performative autopoietic feedback loop, interaction between actors and spectators.

\section{New theatre for a new age and a new spectator}

The similarities between the ideas of Vetrnica, Pekarna, Pupilija and Glej, as well as other neo-avant-garde groups of the 1970s, including the OHO group, are evident. Lado Kralj's reflections, the mini-manifesto of the Pupilija Ferkeverk group, Tomaž Kralj's short programme notes, and Vlado Šav's reflections on his group Vetrnica all speak about a specific form of experimental theatres that emerged in Slovenia at the turn of the 1960s to the 1970s, in interaction with the student movements and alternative culture. These collaborative communities and collectives paved the way for the non-institutional scene with a specific aesthetic diversity, radicalism and consistency:

There are many performances, their array spanning from ritual theatre to the so-called "upgraded realism", which introduced utterly new principles of horizontal dramaturgy with a different sensibility/awareness of time, which in this dramaturgy substitutes verticality. [...] Members of this company are neither better nor smarter than the next man; they merely have infinitely more opportunities to experiment in their own social environment, representing a consistent approximation to the ideal of self-management, author, director, costume designer, technician, etc. (Božič, "Eksperimentalno pozorište” 320).

The theatre communities of the 1970s were aesthetic revolutions that turned their focus towards the ritual presence of someone who was not acting but being in reality. They all proceed from the postulates of Artaud's theatre, from his realisation that theatre, which made use of Western psychology's "obsession with the defined word 
which says everything", led to "the withering of words" (Artaud 118). They try to add "another language to the spoken language, and I am trying to restore to the language of speech its old magic [...] for its mysterious possibilities have been forgotten" (Ibid. 111). Thus, Glej, Pekarna, Pupilija and Vetrnica became involved in what Rudi Šeligo called "immediate presence", a specific presence.

They also introduced special acting-performing methods through which they tried in their performances to find a new type of acting that would stem from the actor's very blood, body, biology and situation. Thus Lado Kralj, Vlado Šav, Dušan Jovanović and Tomaž Kralj, each in their own way, carried our aesthetic, performative revolutions emancipating both performers and spectators in the sense of Jerzy Grotowski, Richard Schechner and Eugenio Barba. Schechner's ritualism was present in the first three performances by the Pekarna Theatre: Dane Zajc's Pathwalker, directed by Lado Kralj (1972); Gilgamesh, directed by Ivo Svetina (1972) and Rudi Šeligo's Let Me Cover You with Leaves, directed by Lado Kralj (1973). Jerzy Grotowski's influence was primarily felt in the performances and actions of the Vetrnica group in the 1970s: Srečanje (The Meeting, 1974); Soočanje (The Confrontation, 1974); Kopanje (Bathing, 1975) and the community in Petkovci (1976-1980). But all the artistic communities and groups shared a specificity of collective creation in which the performance before the public was not the main goal. Their focus was a specific process of creation, as well as the interaction of all participants. Their goal was a new type of actor, or rather performer, whom Ivo Svetina describes: "All performers were becoming agents, a new type of actor who was no longer based on 'enacting' individual drama characters, but rather used their individual energy and presence, gesture and spoken word to give a new image to poems as well as their authors" ("Prispevek za zgodovino" 41).

Barbara Orel claims that the series of performances and performative procedures triggered in that period's theatre should be understood as the defining moment in Slovenian theatre history when the "transition to performance art" took place. They also provided a "fascinating confrontation with reality" in their descent from literature to immediate stage presentation: "The assemblage of scenes, from the introductory urban ritual - watching the TV evening news and thus the world as it appears in the moment of performing, to the concluding ritual of slaughtering the chicken, was founded in a dedicated and ruthless exploration of the real" (Orel, "Pupilija" 196).

This ritual of slaughtering the chicken can be interpreted in the sense of Maurice Blanchot when he makes the following point in The Unavowable Community:

The "basis of communication" is not necessarily speech, or even the silence that is its foundation and punctuation, but exposure to death, no longer my own exposure, but someone else's, whose living and closest presence is already the eternal and unbearable absence, an absence that the travail of deepest mourning does not diminish. And it is in 
life itself that that absence of someone else has to be met. It is with that absence - its uncanny presence, always under the prior threat of disappearing - that friendship is brought into play and lost at each moment, a relation without relation other than the incommensurable. (25)

As demonstrated in the cases of Pupilija, Pekarna and Vetrnica, the studentexperimental theatre blurred the boundaries between artistic genres, high and low culture, professional and non-professional actors. It was derived from novel theories of art and culture as argued for by, for example, Lado and Tomaž Kralj and Taras Kermauner, who built on Artaud, the American theatre avant-garde, Grotowski and Schechner. By breaking down boundaries and taboos, this theatre created a new, liberated performative territory, from which the alternative theatre and culture of the 1980s and the non-institutional performing arts scene of the 1990s emerged, as well as, to a certain degree, today's post-repertory theatre in its more daring forms.

However, we should not forget that this theatre also created something that became very important for the positioning of the independent theatre and artistic scene of the late socialism and post-socialism, and can be linked to Nancy's notion of community as a specific singularity: "Community means, consequently, that there is no singular being without another singular being, and that there is, therefore, what might be called, in a rather inappropriate idiom, an originary or ontological 'sociality' that in its principle extends far beyond the simple theme of man as a social being (the zoon politikon is secondary to this community)" (28).

And the utopian idea of communism as a society without classes and fixed roles was, of course, very close to Pekarna, Pupilija and Glej of the 1970s, the aesthetic revolutions that took Georges Bataille's idea (as interpreted by Nancy) very seriously that "the pole of community was, for Bataille, bound up with the idea of communism. This included, in spite of everything, themes of justice and equality; without these themes, regardless of the way one chooses to transcribe them, the communitarian enterprise can only be a farce. In this respect at least, communism remained an unsurpassable exigency, or, as Bataille wrote, 'In our times the moral effect of communism is predominant." (20).

For the Slovenian experimental communities under Yugoslav self-management socialism, the idea of communism, as well as its moral effects in a good and bad sense, were more than present. They had to cope and face all the vulgarisations of the community and communism, but their primary aim was to establish new modes of artistic communities.

Thus, we can confirm the hypothesis suggested by Rok Andres: Lado Kralj's programme (as well as those of Vlado Šav, Dušan Jovanović and Tomaž Kralj) to a 
significant extent "corresponded to the current theatre moment, for what else are audience participation, specialised psycho-physical training of actors, ritual elements of theatre, team (group) creation of performances, new possibilities offered by the visual and audio elements of performance, but elements of contemporary (dare we say, post-dramatic) theatre?" (26).

Meanwhile, all avant-garde groups at the turn of the 1960s to the 1970s ought to be understood in connection with the hippie culture, its ludic elements, the student and civil movements such as the new-left movements, the critique of culture (and politics) of their fathers and to new art practices. Miško Šuvaković thus concludes that this means "there are no longer any clear stipulations of what theatre, literature, visual arts and film actually are". Thus, theatre became a thing of the tribe, which set off to discover "its sociality and presented it through art" (Tanko, 1585). In the avant-garde student theatre, these genres and tactics entered into an intensive mutual dialogue and began working in an experimental, sometimes excessive, way. This generation needed to redefine its artistic and social role, which undoubtedly led to abolishing the hierarchy between the repertory and the experimental, the professional-drama and the amateur-student theatre.

And to conclude with some thoughts from Bojana Kunst on collaborative works and communities from the 1960s and 1970s:

The collaborative other is present only through an immediate freedom of choice and exactly with this freedom of choice he/she also gets his/her body, his/her senses, his/ her very particular desires and creative energies. Therefore, the endless participatory freedom of bodily collaborators, the spontaneity of the democratic communities from that period, are only possible through a series of strict protocols which, precisely because they are merely technical, enable a "free" scenario for collaboration. Participatory freedom is thus always the freedom of realisation through a certain protocol, which in turn allows us to participate and do whatever we desire without interruption. Which we can qualify as a paradox, because every form of participatory freedom requires the same scenario. The paradox that is today in the core of the contemporary production of desire, where scenarios for freedom are increasingly unified, privatised and controlled. (80)

In this sense, we can interpret the history of the Slovenian experimental theatre and performing arts scene from the 1970s (the decade in which both Glej and Pekarna community theatres were established and had their artistic and conceptual peaks) as a period of constant attempts to form the community in art as defined by a French philosopher Jean-Luc Nancy: "Community on the contrary is ordinary being together, without any assumption of common identity, without any strong intensity, but exposed to banality, to the 'common' of existence." (XIII)

Moreover, at the same time, the attempts to re-establish a modern form of community 


\section{Conclusion: From late socialism to post-socialism}

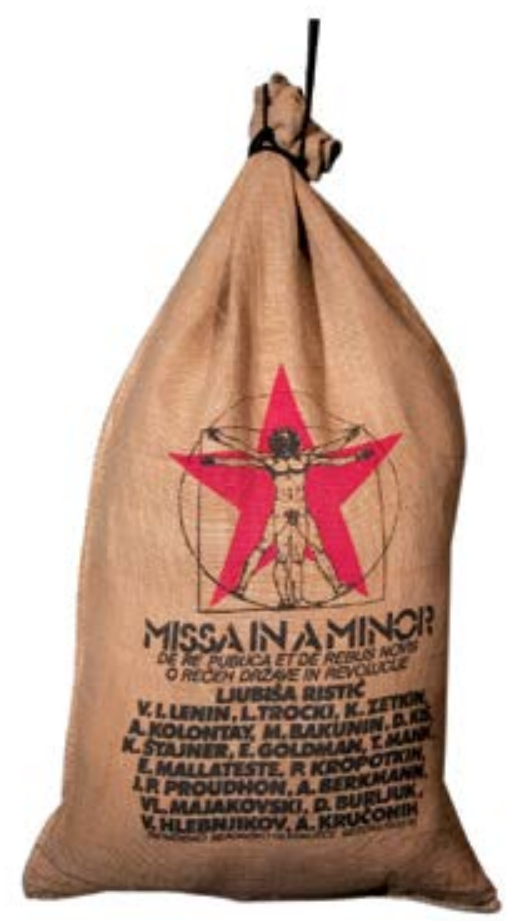

An artefact by Matjaž Vipotnik for Missa in a minor by Ljubiša Ristić, Mladinsko Theatre, 1980, Mladinsko Theatre Archive.

The "cultural struggle" between official and experimental continued well into the 1980s. At its beginning, the leading Slovenian cultural ideologue, Josip Vidmar, as a president of Sterijino Pozorje in Novi Sad, described Jovanović and Ristić as cultural terrorists.

At the start of the 1980s, Jovanović, Ristić and Marko Slodnjak developed the new, specific non-hierarchical structure of the Mladinsko Theatre based on the models of the Berlin Schaubühne of Peter Stein, the Theatre du Soleil of Ariane Mnouchkine and the Tanztheatre Wuppertal of Pina Bausch. Its protagonists were the author and the director, and its tools were the space and the body, as well as a specific, Brookian 
and Brechtian approach towards acting. Critics denoted this infelicitously as the ensemble-acting phenomenon. In contrast, it should essentially be understood as a holistic, political and especially artistic engagement on the part of the acting team for an individual performance, for the theatre as a whole and for the entire collective of artists cooperating in the individual theatrical project. The new understanding of theatre and its attitude towards reality, and the understanding of the whole literarydramatic-critical apparatus, which, at the turn of the decade, was introduced most radically by Ristić and Jovanović, was initiated by Taras Kermauner in his nowadays sadly little known but lucid and daring paper "Comments on Direction or How the Directed Director Deciphers His Direction".

He differentiated between "half-past" and hyper-modernist directors, between the two approaches towards theatre, which, with the support of conservative criticism, conflicted precisely given Ristić's and Jovanović's (and, before them, Mile Korun's) performances on the transition from the 1970s to the 1980s.

The criticism that tries to destroy the significance and value of theatrical hypermodernism (Josip Vidmar), incessantly calls upon the intangibility of dramas; it takes away the right of the directors to interpret the drama of the world or even to transform it. [...] Placed face to face as opponents are not the half-past classically bourgeois and the hyper-modernist directors, but the latter and the half-past critic - the ideologist. As to his nature, the half-past director is actually the observer of the law ... In the fight against the hyper-modernist, he is therefore replaced by the one who is the first-sworn and nationally and institutionally appointed - the interpreter of holy books: the literarycultural ideologist. (Kermauner, quoted in Toporišič, Med zapeljevanjem 118-119)

This conflict culminated in the Ristić/Jovanović/Vidmar polemics at the Sterijino pozorje festival of Yugoslav drama and in Josip Vidmar's labelling of them as "cultural terrorists". Vidmar, who declined Missa in a minor, along with practically all-contemporary Slovenian theatre, did not consider it appropriate to see the performance. In an interview for the daily newspaper Delo, he stated that he was also told what Ristić demanded from his spectators - to sit on footstools, that is. He added that the fact the director would be directing him as well as something to which he did not want to treat himself. In contrast to him, however, most of the critics defended the performance as a pinnacle one.

The main characteristics of this kind of political and explorative theatre were precisely the linking of political engagement and theatrical experiment, the revolution of the mind and form. Interestingly, it sprang from the reading of tradition, e.g., that of Bertolt Brecht, Peter Brook and his staging of the documentary theatre of Peter Weiss (Marat-Sade), Heiner Müller and his premise that as many actions as possible should be shown simultaneously, Ariane Mnouchkine and her early projects on revolution 
While neglected at home, in Slovenia and Yugoslavia, this theatre had successful international performances. A very interesting example is Missa in a minor (1980) which did not receive any of the awards at the leading Slovenian national theatre festival (Borštnikovo srečanje, known today in English as Maribor Theatre Festival) but became the first Yugoslav performance to receive the Grand Prix at the then extremely important international BITEF festival event in Belgrade and one of the first in-depth critiques of Slovenian theatre in the leading German theatre magazine Theatre Heute.

With Missa in a minor, Ristic developed a specific form of theatre that used to his advantage the most varied visual and phonic facets of the performance, and, with a non-classical attitude to the text or by creating Barthesian written texts, he creates a typical post-dramatic and Eco's open work. In the following decades, this property remained one of the most recognisable peculiarities of the poetics of youth and noninstitutional theatre in general, which Western theatre critics and the profession recognised as a speciality of Slovenian theatre (later also contemporary dance).

The specificity of the Mladinsko Theatre was perceived by the audiences and critics time and time again. It was referred to as "ensemble acting", which initially sprang specifically from the theatrical organism and the acting approach cultivated by the Berliner Ensemble, though this connection was lost later on.

A similar specificity can be seen in the concept of Ljubiša Ristić's "utopic idea" of a new structure KPGT, an acronym formed from the words for theatre in the corpus of languages spoken in Yugoslavia: kazalište, pozorište, gledališče, teatar. His concept was based on a multi-notional cultural concept. With his close associates (Nada Kokotović, Dušan Jovanović, Rade Šerbedžija, Dragan Klaić, Dušan Jovanović, etc.), in 1977 Ristić formed this supra structure to produce The Liberation of Skopje in Zagreb, written and directed by Dušan Jovanović. In the 1980s, this structure slowly became a specific network (of artists, institutions, performances, aesthetics, etc.) and a theatre brand with participating artists from several theatre institutions mostly led by KPGT-related artists in Ljubljana, Zagreb, Novi Sad, Subotica, Skopje, etc. Rok Vevar describes the new situation emerging after the death of Josip Broz Tito:

In the mid-eighties, when Ljubiša Ristić took over as the manager of the National Theatre in Subotica, the KPGT based itself there, while in this period the cultural programmes of the KPGT (festival, repertoires, etc.) also started functioning as a peculiar collection of artistic works. That is, they became some sort of a theatre depot in which the performances of the KPGT collaborators were nearly catalogue units, which particularly Ljubiša Ristić could, at any time, (again) pull out from the warehouse and stage in a selected theatre in the SFR Yugoslavia. From the mid-nineties, the KPGT is the name 
of an artistic programme and ensemble based in the former sugar factory (Šećerana) in Belgrade that operates there as a local theatre. After the dissolution of the SFRY, due to the collapse of the common political space, the Serbian nationalist usurpation of the idea of the Yugoslavhood in political disagreements of the eighties and Ristićs participation in the JUL (Yugoslav Left) party, a number of its artistic protagonists and collaborators, distanced themselves from the KPGT concept. Some did so publicly, some simply refused to talk about it any longer. Ljubiša Ristić still insists that the idea of the common cultural space is pertinent (and is particularly critical of treating the western Balkans as a "region", in the way the European Union does it), regardless of the fact that the political structure called SFRY collapsed. ("KPGT"17)

KPGT shared with the Mladinsko what dramaturg Marko Slodnjak termed "the theatrical metaphor of the political" that strongly marked the repertoire of both theatres in the first half of the 1980s. But let us concentrate on the Mladinsko.

The Prisoners of Freedom (Ujetniki svobode, 1982), written by Emil Filipčič and directed by the young director Janez Pipan, followed Missa in a minor. The ludic playfulness and political provocativeness of the performance took the Slovenian cultural public by storm. It outlined the individuality of the Mladinsko Theatre phenomenon in both the former Slovenian and wider Yugoslav spaces. This was well mirrored by Pipan's thinking in an interview at the time for the weekly Mladina:

At this moment, a prevailing model of Slovene theatre exists, which, in comparison to the theatre of ten years ago, is markedly conservative. It is spasmodic in its efforts to preserve its status and repressive towards everything that appears outside of that mode. Watching such performances, I get the feeling that, within several months, these theatres will have demolished all of what has been built over the past several years or even the past decade: as if the theatres forgot about the experimental work, such as that of the Glej or the Pekarna. They have forgotten about the innovative and more radical theatres that have brought a new vision and formulation to the theatrical world. Performances made in the manner of fifty years ago are advocated as valuable without the right of appeal. Consequently, texts by young authors are ejected from programmes and younger artists are driven away from the theatres, having no chance of working (an example is The Christmas Crib / Jaslice by Valentin Duša at Glej Theatre) and that theatrical criticism nips in the bud any attempt by younger theatrical creators to enter this big organism, the Slovene theatrical institution. An organism, which, in my opinion, is dead. We must prevent the sterilisation and regression of Slovene theatre. (Quoted in Has the Future 124)

Pipan's thinking clearly presents the Slovenian theatrical situation in the first half of the 1980s and, of course, the new programme scheme of the Mladinsko Theatre. At the première of The Prisoners of Freedom, Andrej Inkret wrote in the newspaper Delo: "A wild performance that connects the play with the ideology and style of the so-called contemporary alternative culture" (Za Hekubo 326). 
It is quite clear that Ristic and the Mladinsko Theatre, with its variant of political theatre, announced the entry of art into the field of politics and that this remained characteristic of the entire Neue Slowenische Kunst (NSK) movement. However, in contrast to KPGT, which deliberately built a communication model that allowed the audience to identify, NSK no longer allowed this but built on double coding, overidentification and sliding markers.

In the same period, however, the next generation with Neue Slowenische Kunst confidently declared, "theatre is a state" and, at a time when the Yugoslavia that the KPGT tried to defend disintegrated, established its own NSK State. However, the members of NSK were not labelled as cultural terrorists but rather as fascists or remnants of the Western avant-garde, which were ideologically controversial and

far from the working class in terms of progress: Since the working class is in power, our society is already, as such, avant-garde. The socialist country does not need special avant-garde artists, as it is avant-garde in itself. [...] So, of course, it is clear that in our post-war history, the idea of the avant-garde could appear only as a fantasy of those who fought against the new working class and political avant-garde they did not understand. And society was absolutely right when it marked avant-garde attempts as backward, as they were usually identified with the Western avant-garde, which, however, are avantgarde only from the point of view of the bourgeois class, that is to say - as is generally known - one that is far behind the workers in terms of progress. (Mikuž, Slovensko 199)

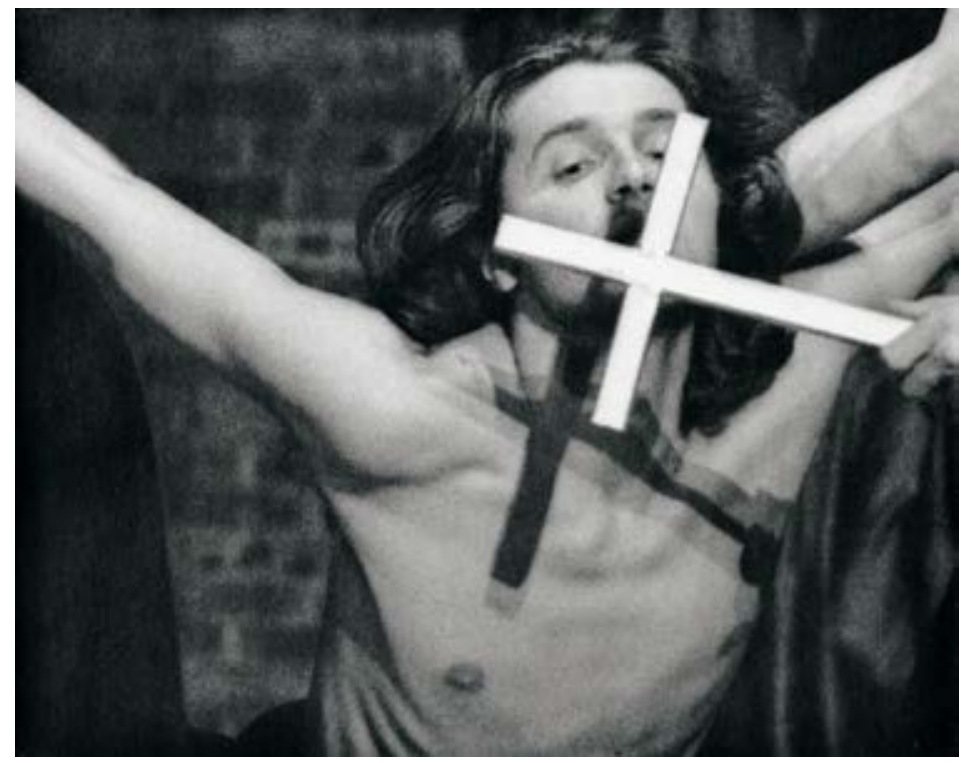

Missa in a minor, Mladinsko Theatre, 1980. Photo: Mladinsko Theatre Archive. 
Thus history once more organised itself in a series of repetitions. In the late 1980s, the Slovenian experimental theatre scene was far from being just on the margins of society. Nevertheless, it still did not become a part of mainstream culture. One could say that it found itself in a schizophrenic position: at the margins of the national semiosphere and slowly moving towards the centre of the European festival semiosphere. Theatres on the periphery of the national semiosphere have produced specific aesthetic and institutional revolutions, qualities that make them more perceived, valued and ranked on the international festival scene than the Slovenian repertory theatrical scene.

From 1970 to 1990, the Slovenian experimental and non-institutional performing arts scene created new, specific modes of non-hierarchical aesthetics and creativity, changed how the groups and theatres were organised and led and formed temporary communities with emancipated audiences. To develop their own logic of devised and collaborative theatrical tactics, these new models turned to heterogeneous models from Grotowski, Schechner and Barba to Mnouchkine Peter Stein and Pina Bausch.

These collaborative artistic tribes significantly changed the theatrical landscape in Slovenia and Yugoslavia and led to new models and aesthetics from the 1990s until today. New or other theatre, practised by various groups, gradually overwhelmed Yugoslav and European festivals of alternative and student theatre. They became synonymous with the resilience and endurance of small theatre groups that proliferated during the 1970s and 1980s, partly merging with the phenomenon of the first non-repertory professional theatre with an ensemble of actors, the Mladinsko Theatre, on the one hand, and new initiatives of the "independent" and later "noninstitutional" theatrical and artistic scene on the other. However, that is a new story that must be examined closely and retold in the near future. 
Adorno, Theodor W. Aesthetic Theory. Continuum, 2004.

Andres, Rok. "Mitologija po meri človeka." Gledališka alternativa sedemdesetih in osemdesetih. Academy of Theatre, Radio, Film and Television, University of Ljubljana, 2012.

Artaud, Antonin. Theatre and Its Double. Grove Press, 1958.

Badiou, Alain. Rhapsody for the Theatre. Translated by Bruno Bosteels and Martin Puchner. Verso, 2013.

Blanchot, Maurice. The Unavowable Community, trans. Pierre Joris, Station Hill Press, 1988.

Božič, Peter. "Eksperimentalno pozorište kao socijalni fenomen iz izkustva slovenskih eksperimentalnih pozorišta" Pozorište, vol. XVII, no. 5-6, 1975, pp. 311-322.

-. "Razvoj gledališke literature in gledaliških sredstev v slovenskem gledališču." Maske : revija za gledališče, vol. 2, no. 1, 1986, pp. 37-42.

Čufer, Eda. "Naša stvar." Sodobne scenske umetnosti, edited by Bojana Kunst and Petra Pogorevc, Maska, 2006, pp. 28.

EG Glej. 20 let EG Glej. EG Glej, 1990.

Fischer-Lichte, Erika. Estetika performativnega. Študentska založba, 2008.

“Gledališče Pupilije Ferkeverk", Studentski list, vol. XXV, no. 8, 1970.

Grotowski, Jerzy. Revno gledališče. Mestno gledališče ljubljansko, 1973.

Huizinga, Johan. Homo Ludens: A Study of the Play-Element in Culture, Routledge, 2009. Inkret, Andrej. Milo za drago. Knjižnica MGL, 1978.

—. Za Hekubo, gledališka poročila 1978-1999. Slovenski gledališki muzej, 2001.

Innes, Christopher. Avantgarde Theatre. 1892-1992. Revised and updated edition of Holy Theatre 1981, Routledge, 1993.

Jesenko, Primož. "The Edge in the Centre." Occupying Spaces, Experimental Theatre in Central Europe, edited by Ivo Svetina et al., SLOGI, 2010.

Jovanović, Dušan. "Pleme, konfrontacija in kolaž." Prišli so Pupilčki: 40 let gledališča Pupilije Ferkeverk, edited by A. Milohnić and I. Svetina, Maska, Slovenski gledališki muzej, 2009, pp. 89-100.

—. "Odgovor na Anketo 'Mladi o Akademiji za gledališče, radio, film in televizijo'." Naša sodobnost, vol. 17, no. 11, 1969, pp. 1171. 
“Kazališna gerila dobiva rat.” Vjesnik, 12 August 2016, http://www.kpgtyu.org/ pressarhiva/displayimage.php?album=lastup\&cat=7\&pid=8015\#top_display_ media. Accessed on 23 April 2019.

Kermauner, Taras, Jože Koruza, Janko Kos, Lado Kralj, Vasja Predan, Borut Trekman, Josip Vidmar. "Slovenska gledališka situacija." Sodobnost, vol. 17, no. 6, 1969, http:// www.dlib.si/?URN=URN:NBN:SI:DOC-QL6YTAPQ

Kirby, Michael. "On Acting and Not-Acting." The Drama Review: TDR, vol. 16, no. 1, 1972, pp. 3-15.

Kozak, Primož. Peter Klepec v Ameriki, Obzorja, 1971.

Kralj, Lado. “Čutil sem, da v slovenskem prostoru manjka ritualni princip." Dialogi, vol. 45 , no. $11 / 12$, 2009, pp. 3-37.

—. "Mednarodni festival študentovskih gledališč v Zagrebu." Sodobnost, vol. 12, no. 12, 1964, pp. 1238-43.

-. "Zanima me razredno gledališče" (Zajec, M., interview with Lado Kralj) Mladina, vol. 21, no. 12, 1971, pp. 20-21.

—. "Hipijevsko, čutno, razpuščeno." 20 let EG Glej, edited by Marko Crnkovič et. al., EG Glej, 1990, no pag.

Kunst, Bojana. "Communities and other models of cooperation and friendship from the 60's until now." L'Observatoire, vol. 18, no. 33, 2008, pp. 79-81.

Mikuž, Jure. Slovensko moderno slikarstvo in zahodna umetnost. Moderna galerija, 1995.

Orel, Barbara. "Pupilija kot zareza v režimu predstavljanja in zaznavanja." Prišli so Pupilčki: 40 let gledališča Pupilije Ferkeverk, edited by A. Milohnić and I. Svetina, Maska, Slovenski gledališki muzej, 2009, pp. 195-213.

-. "Experimental Theatre." Platform: East European Performing Arts Companion, Adam Mickiewicz Institute [etc.], 2016, pp. 295-305.

Povše, Janez. "Pot." Mladina, 15 September 1970, pp. 20-21.

Prišli so Pupilčki: 40 let gledališča Pupilije Ferkeverk. Milohnič, edited by Aldo and Ivo Svetina, Maska, Slovenski gledališki muzej, 2009.

Pavis, Patrice. "Od besedila do odra, težaven porod." Prisotnost, predstavljanje, teatralnost. edited by Janez Janša (Emil Hrvatin), Maska, 1996, pp. 141-158.

Schuller, Aleksandra. "Vlado Šav in aktivna kultura." Annales. Series historia et sociologia, vol. 21, no. 2, 2011, pp. 397-412.

Slana, Miroslav. "Zdenko Kodrič - Koči." Stop, vol. 23, no. 27, 1990, pp. 10-11.

Svetina, Ivo. "Prispevek za zgodovino gledališkega gibanja na Slovenskem - Pupilija Ferkeverk." Prišli so Pupilčki: 40 let gledališča Pupilije Ferkeverk, edited by A. Milohnić and I. Svetina, pp. 27-79. 
—. Gledališče Pekarna 1971-1978. Mestno gledališče ljubljansko, 2012.

Šav, Vlado. "Gledališče kot intenzivno življenje." From an interview with the leader of Vetrnica Lado Šav. Dnevnik, 20 December 1974, p. 4.

"Študentsko gledališče Vetrnica", Mladina, 5 December 1974, p. 20.

Nancy, Jean-Luc. The Inoperative Community, edited by Peter Connor, University of Minnesota Press, 2004, p. XIII.

Tanko, Petra. "Čas za revolucijo: (ob 40. obletnici nastanka skupine Pupilija Ferkeverk)." Sodobnost, vol. 11/12, no. 73, 2009, pp. 1583-1592.

Taufer, Veno. "Rudi Šeligo: Ali naj te z listjem posujem?" Naši razgledi, vol. 22, no. 3, 1974, pp. 154, 155.

-. Odrom ob rob. DZS, 1977.

Toporišič, Tomaž. Med zapeljevanjem in sumničavostjo. Maska, 2004.

—. "Performativni obrat Pupilije Ferkeverk." Prišli so Pupilčki: 40 let gledališča Pupilije Ferkeverk, edited by A. Milohnić and I. Svetina, pp. 215-31.

- . Levitve drame in gledališča. [The Metamorphoses of Drama and Theatre], Aristej, 2008.

Toporišič, Tomaž et al. (eds.). Has the Future Already Arrived?, Slovensko mladinsko gledališče, 2007.

Troha, Gašper. "From Theatre Experiments to National Institutions: Lado Kralj and Dušan Jovanović between 1968 and the 1980s." Slavica Tergestina, vol. 24, no. 1, 2020, pp. 208-229.

Vevar, Rok. "KPGT." Kompleks Ristić [Ristić Complex], Gledališki list SMG in HNK Ivan pl. Zajec Rijeka, October 2015.

Vodopivec, Peter. Od Pohlinove slovnice do samostojne države. Slovenska zgodovina od konca 18. stoletja do konca 20. stoletja. [From Pohlin's Grammar to the Independent State], Založba Modrijan, 2007. 